Каряка Інна

кандидат психологічних наук, доцент, доцент кафедри педагогіки та психології професійної освіти

Національного авіаційного університету https://orcid.org/0000-0002-9570-7660

Хорощак Юлія здобувач вищої освіти спеціальності 053 «Психологія» освітньо-професійної програми «Практична психологія» Національного авіаційного університету

DOI https://doi.org/10.35619/praprv.v1i16.220

\title{
ПІСОЧНА ТЕРАПІЯ ЯК ЗАСІБ ЗНИЖЕННЯ ТРИВОЖНОСТІ У ДІТЕЙ СТАРШОГО ДОШКІЛЬНОГО ВІКУ
}

Анотація. У статті розкрито сутність поняття «тривожність», а також проаналізовано основні чинники виникнення даного явища, особливості його протікання, охарактеризовано особливості прояву поведінки дітей з тривожністю: агресія та фантазування. Висвітлено відмінності тривожної поведінки дівчат та хлопчів старшого дошкільного віку та проаналізовано наслідки закріплення даної характеристики. Актуалізується проблема корекиї тривожності у дітей дошкільноого віку, адже в даний період існує ризик закріплення ї̈ як властивості особистості.

Також в статті описується проведене експериментальне дослідження спрямоване на корегування тривожної поведінки дітей старшого дошкільного віку методами пісочної терапії. Надаються результати проведеного дослідження, розглядається методичний інструментарій, за яким воно здійснювалося, наводиться кількісний та якісний аналіз отриманих даних, а також описуються підсумки дослідження - порівняння результатів до проведення психокорекиії та після. За аналізом результатів дослідження, констатується наявність кількісних змін в результатах до та після корекиії, щзо доводить ефективність використання технік пісочної терапії при роботі з даною віковою групою. 3 'ясовується, щуо рівень самооцінки, особливості дитячо-батьківських стосунків та психологічний клімат у сім'ї є основними чинниками формування тривожної поведінки дітей старшого дошкільного віку.

Ключові слова: пісочна терапія, тривожність, дошкільний вік.

Постановка проблеми. Актуальною проблемою сучасної психологічної практики виступає тривожність дітей дошкільного віку, адже даний феномен негативно впливає не лише на емоційне самопочуття дитини, а й знижує рівень функціонування психічної активності в цілому: негативно впливає на формування самооцінки та рівня домагань дитини, пригнічує потяг до навчання, сприяє прояву ригідності мислення, гальмує творчі здібності та уяву, дезорганізовує продуктивність пам'яті, тощо. Все це сприяє формуванню деструкції психічної діяльності дитини, гальмує іiї особистісний розвиток i, як наслідок, може призвести до патопсихологічних розладів. Відповідно до цього, слід зазначити, що на сьогоднішній день, серед засобів, які застосовують з метою профілактики і корекції тривожності у дітей дошкільного віку найбільш вживаними є такі методи: метод зняття нервово-м'язової напруги (Буянов, 1990; Габурєєва, 2000); прийоми прогресивної релаксації (Ассаджолі, Левіс, Левіс); психогімнастика (Ємельянов, 1997; Ісуріна, 1982); психогімнастика, метод систематичної десенсибілізації; техніка аутогенного тренування; метод соціально-психологічного навчання; метод психотерапії, ігротерапія, казкотерапія, лялкотерапія, арт-терапія та іï різновиди і т.д. Проте, на нашу думку, одним із 
найефективніших методів впливу для зниження тривожності у дітей даної вікової категорії $\epsilon$ пісочна терапія, поліфункціональність впливу якої розповсюджується на всі канали психічної активності дитини: перцептивної, когнітивної, емоційної, поведінкової та особистісної сфери.

Аналіз останніх досліджень проблеми. Вивчення даної тематики здійснювалося рядом вчених, науковий інтерес яких стосується пошуку причин, ознак, прояву та наслідків тривожної поведінки. Так, російський психолог Прихожан (2000) розглядає тривожність, як особистісне утворення, яке має когнітивний, емоційний i операціональний аспекти. Науковець зауважує, що тривожності властива всім людям і $є$ необхідною для оптимального пристосування людини до умов життєдіяльності. У свою чергу, Ханін (1980) розрізняє тривожність як ситуативну тривожність, що виникає як реакція людини на різні, найчастіше соціально-психологічні стресори та особистісна тривожність, що проявляється в схильності людини сприймати загрозу своєму «Я» в різноманітних ситуаціях і реагувати на ці ситуації включенням ситуативної тривожності. На думку Нємова, тривожність визначається як властивість людини переходити у стан підвищеного занепокоєння, відчувати страх і тривогу в специфічних соціальних ситуаціях (2001, с. 631). У психологічному словнику Петровського і Ярошевського тривожність розглядається як схильність індивіда до переживання й тривоги, що характеризується низьким порогом виникнення реакції тривоги (1985, с. 292). Кононко (2004) та Колосова (2004) зазначають, що порушення стосунків між батьками та дисгармонія в дитячо-батьківських стосунках сприяє формуванню емоційної нестійкості у дитини, порушує її соціальні орієнтири, руйнує довіру до світу та можливість вільного спілкування 3 оточуючими формує дитячу тривожність. На думку Перлза «...формула тривоги дуже проста: тривога - це пролом між зараз і потім» (1995, с. 145).

Відповідно до цього, можна сказати, що тривожність є негативним емоційним переживанням людини, що пов'язане з передчуттям небезпеки. Поряд зі страхом і надією остання розглядається, як особлива, випереджаюча емоція це і пояснює іiі особливе становище серед інших емоційних явищ.

Мета статті: теоретично обгрунтувати та експериментально дослідити особливості впливу пісочної терапії на зниження тривожності дітей старшого дошкільного віку.

Виклад основного матеріалу дослідження. Вивчення тривожності $\epsilon$ одним iз актуальних питань сучасної психологічної науки. Тривожність у дітей старшого дошкільного віку розглядається в широкому контексті, зокрема виділяють такі чинники ії формування як: соціальна ситуація розвитку дитини, особливості сімейних стосунків та взаємодія педагогів 3 дітьми в процесі виконання різних видів діяльності.

Якщо серед усіх якостей дитини значний прояв має тривожність, то як наслідок, в поведінці дошкільника неодмінно будуть виникати прояви страхів, та можуть виникати невротичні риси, як частина тривожної поведінки. Риса характеру - тривожність - це песимістична настанова на життя, коли вона виникає, уявлення дитини про життя стає наповнене погрозами і небезпекою. Невпевненість породжує тривожність і нерішучість, а вони, в свою чергу формують відповідний характер. У емоційному настрої тривожності переважає почуття страху, хвилювання вчинити не правильно, не відповідати загальноприйнятим вимогам і нормам розвивається ближче до 7 й особливо 8 років при великій кількості нерозв’язних страхів, що йдуть із більш раннього віку. Головним джерелом тривог для дошкільників і молодших школярів виявляється сім'я. Надалі, вже для підлітків така роль сім'ї значно зменшується; проте вдвічі зростає роль школи.

Слід також зазначити, що інтенсивність переживання тривоги, рівень тривожності у хлопчиків і дівчаток різні. У дошкільному віці хлопчики більш схильні до тривожості, ніж дівчата. Це пов'язано 3 тим, 3 якими ситуаціями вони пов'язують свою тривогу, як іiі пояснюють, чого побоюються. I чим старше діти, тим помітніше ця різниця. Дівчата частіше пов'язують свою тривогу з іншими людьми. До людей, з якими дівчата можуть пов'язувати свою тривогу, відносяться не тільки друзі, рідні, вчителі, дівчата бояться так званих «небезпечних людей» - п'яниць, хуліганів і т.д. Хлопчики ж бояться фізичних травм, 
нещасних випадків, а також покарань, які можна очікувати від батьків або поза сім'єю: вчителів, директора школи і т. д.

Щодо наслідків тривожності, то варто зазначити, що дана особливість, цілком не впливає на інтелектуальний розвиток дитини, проте високий ступінь тривожності може негативно позначитися на формуванні дивергентного (тобто креативного, творчого) мислення, адже для творчості особливо важливими є такі риси, як відсутність страху перед новим, невідомим. Позитивним моментом, можна вважати, те, що тривожність у старших дошкільників не є стійкою рисою характеру й відносно оборотна при проведенні відповідних психолого-педагогічних заходів, а також можна істотно знизити тривожність дитини, якщо педагоги й батьки, що виховують його, будуть дотримуватися потрібних рекомендацій. Ми провели експериментальне дослідження, учасниками якого стали 40 осіб даного віку, які $\epsilon$ вихованцями дитячих навчальних закладів м. Києва, з метою виявлення рівня сформованості тривожності у дітей старшого дошкільного віку. У процесі роботи нами було використано ряд психодіагностичних методик: тест «Вибери потрібне обличчя» (авт. Теммл, Доркі, Амен), «Сходинки» (авт. Щур) та «Малюнок сім’і»».

За результатами методики на визначення рівня тривожності «Вибери потрібне обличчя» було констатовано, що 70\% дітей мають середній рівень тривожності, 30\% високий рівень особистісної якості. Низького рівня сформованості тривожності виявлено не було. Як відомо, діти 3 середнім рівнем тривожності не відчувають себе повністю захищеними. Вони турбуються 3 приводу самотності та негативних взаємин з батьками i однолітками. Все ж тривожні переживання простежуються у них лише час від часу, ситуативно. Ці діти рідко йдуть першими на контакт, не проявляють ініціативу, спокійно поводять себе під час ігрової діяльності та спілкування. Третина респондентів, які мають високий рівень сформованості тривожності, мають труднощі в адаптації. Вони відчувають дискомфорт у незнайомому оточенні, постійну тривогу та небезпеку, є схильними до переживань страхів (як реальних, так і уявних), мають труднощі у стосунках.

За результатами методики «Сходинки» було констатовано, що $60 \%$ досліджуваних мають завищену самооцінку. 40 \% дітей мають адекватну самооцінку. Заниженої самооцінки в учасників дослідження не виявлено. За результатами діагностичних спостережень встановлено, що діти 3 завищеним рівнем самооцінки $є$ більш демонстративними, орієнтуються на бажане, не здатні реально оцінювати власні сили, їм притаманна стійкість $\mathrm{i}$ недостатня адекватність. Досліджуваним з адекватною самооцінкою притаманне адекватне ставлення до власних успіхів та невдач. Вони чітко пояснюють свої дії, посилаючись на реальні ситуації і досягнення.

Щодо визначення особливостей взаємовідносин у сім'ї та стилю дитячо-батьківських зв'язків, діагностика яких було проведено за допомогою методики «Малюнок сім'ї» було виявлено, що 90\% досліджуваних мають позитивні (теплі) взаємини у сім'ї, 10\% осіб мають нейтральні стосункт. Майже всі діти проживають в повних сім'ях. Стосунки між членами сім’ї характеризуються теплотою та довірою. На дитячих малюнках члени сім’ї зображені на близькій відстані, тримаючись за руки. Це говорить про психологічне благополуччя, яке панує в родині, включеність дитини у сімейний колектив. Переважна більшість дітей намалювали себе між батьками, чим підтвердили тісні зв'язки у спільноті. Незначна частина досліджуваних намалювала своїх рідних віддалено, це може говорити про «дистанцію», яку дитина помічає в житті і виділяє іiі. В окремих малюнках спостерігався пропуск одного 3 батьків, що може свідчити про відсутність уваги, або напружені стосунки. На цих малюнках багато темних кольорів, штрихувань, посторонніх людей та предметів. На нашу думку це свідчення існування певної напруженості у мікрокліматі сім'ї.

Одним із дієвих засобів роботи з тривожністю у дітей дошкільного віку виступає пісочна терапія, теорія якої вперше була сформульована швейцарським психоаналітиком Карлом Густавом Юнгом. Центральне уявлення про можливості пісочної терапії сформульоване так: «Взаємодія з піском надає клієнту нагоду позбутися від психологічних травм за допомогою перенесення зовні, на площину пісочниці, фантазій і формування відчуття зв'язку і контролю над своїми внутрішніми мотивами. Встановлення зв'язку 3 
несвідомими мотивами, особливо 3 архетипом самозвеличення, та їхнє вираження в символічній формі значною мірою полегшують здорове функціонування психіки».

Взаємодія дітей у групі з використанням технік пісочної терапії створює позитивний ефект на емоційний стан учасників: гіперактивних дітей даний метод терапії заспокоює, скутих - розслаблює, тривожних - заспокоює, агресивних - втихомирює. Пісок - це унікальна, натуральна речовина, наділена якостями, які не можливо преоцінити та обрахувати. Також даний матеріал спроможний сформувати в уяві образи певного характеру, які мають лікувальну дію на психіку дитини.

Відповідно до цього, нами було розроблено корекційну програму щодо зниження рівня тривожності у дітей старшого дошкільного віку. Для їі впровадження була сформована експериментальна група з 6 осіб, вибраних за результатами проведеного раніше дослідження.

Мета корекційно-розвивальної програми - здійснити профілактику тривожності; зняття емоційного та тілесного напруження, забезпечення можливостей для формування адекватної самооцінки. Програма розрахована на 6 занять по 30-55 хвилин кожне. Заняття проводиться 2 рази на тиждень.

Головними завданнями програми було:

- зниження загального рівня тривожності дітей;

- напрацювання навички вербалізація почуттів;

- удосконалення навички саморегуляції та самоконтролю;

- формування позитивного самосприйняття й підвищення впевненості дитини.

Переважна більшість вправ полягати у зображенні на піску різноманітних зображень, візерунків та форм , заохоченні взаємодії між дітьми через спільну діяльність та вербалізації почуттів та ідей. Загалом заняття бути спрямовані та зняття емоційного та м'язового напруження, зниження тривожності та розвитку навички комунікації. Тематичний план психокорекційної програми подано в таблиці 4.

Таблиия 4

Тематичний план програми

\begin{tabular}{|c|c|c|c|}
\hline № & Структура заняття & Обладнання & $\begin{array}{l}\text { Тривалість } \\
\text { у хвилинах }\end{array}$ \\
\hline 1 & $\begin{array}{l}\text { Вправи: } \\
\text { «Вітаю тебе, пісок!» } \\
\text { «Піщані візерунки» } \\
\text { «Закопування секретиків» } \\
\text { «Переможемо страх» }\end{array}$ & $\begin{array}{l}\text { ящик з піском, іграшки, } \\
\text { геометричні форми, різні } \\
\text { «чарівні камінці» предмети; } \\
\text { магнітофон, запис із спокійною } \\
\text { музикою. }\end{array}$ & $\begin{array}{c}8 \\
10 \\
10 \\
5\end{array}$ \\
\hline 2 & $\begin{array}{l}\text { Вправи: } \\
\text { «Змійки» } \\
\text { «Занурення рук в пісок» } \\
\text { «Незвичайні сліди» } \\
\text { «Сімейна гра» } \\
\text { «Візерунки на піску» } \\
\end{array}$ & $\begin{array}{l}\text { ящик } з \text { піском, комплект фігурок } \\
\text { повинен містити:тварин, рослин, } \\
\text { будівлі, транспорт, людей. }\end{array}$ & $\begin{array}{c}5 \\
5 \\
5 \\
10 \\
10\end{array}$ \\
\hline 3 & $\begin{array}{l}\text { Вправи: } \\
\text { «Чарівний пісок» } \\
\text { «Відбитки наших рук» } \\
\text { «Пісочний дощик» } \\
\text { «Тематичний світ» } \\
\end{array}$ & $\begin{array}{l}\text { ящик } 3 \text { піском, комплект фігурок } \\
\text { повинен містити:тварин, рослин, } \\
\text { будівлі, транспорт, людей. }\end{array}$ & $\begin{array}{c}5 \\
8 \\
10 \\
10\end{array}$ \\
\hline 4 & $\begin{array}{l}\text { Вправи: } \\
\text { «Міна» } \\
\text { «Візерунки» } \\
\text { «У пісочній країні ідуть дощі» } \\
\text { «Чарівна країна» } \\
\text { «Комплімент» }\end{array}$ & $\begin{array}{l}\text { ящик } 3 \text { піском, вода, розпилювач } \\
\text { для води, комплект фігурок } \\
\text { повинен містити:тварин, рослин, } \\
\text { будівлі, транспорт, людей. }\end{array}$ & $\begin{array}{c}5 . \\
8 \\
8 \\
10 \\
5\end{array}$ \\
\hline
\end{tabular}




\begin{tabular}{|c|c|c|c|}
\hline 5 & $\begin{array}{l}\text { Вправи: } \\
\text { «Загадкові піщані сліди» } \\
\text { «Відбитки» } \\
\text { «Краплини пісочного» } \\
\text { «Хто до нас приходив?» }\end{array}$ & $\begin{array}{l}\text { ящик з піском, вода, розпилювач } \\
\text { для води, іграшки, геометричні } \\
\text { форми. }\end{array}$ & $\begin{array}{c}5 \\
5 \\
10 \\
10\end{array}$ \\
\hline 6 & $\begin{array}{l}\text { Вправи: } \\
\text { «Чарівні камінці» } \\
\text { «Хто до нас приходив?» } \\
\text { «Пісочний дощ» } \\
\text { «Живі камінці» }\end{array}$ & $\begin{array}{l}\text { ящик з піском, вода, розпилювач } \\
\text { для води, фігурки по вибору, } \\
\text { природний матеріал; магнітофон, } \\
\text { аудіокасета із спокійною музикою. }\end{array}$ & $\begin{array}{c}5 \\
10 \\
5 \\
10\end{array}$ \\
\hline
\end{tabular}

Перевірка рівня тривожності учасників експерименту після проведення розвивальнокорекційної роботи засвідчила наявність позитивних зрушень у емоційній сфері дошкільників. Було зафіксовано позитивну динаміку зниження тривожності дітей старшого дошкільного віку. Відтак, можна сказати, що впроваджена психокорекційна програма 3 використанням пісочної терапії позитивно вплинуло на корегування тривожності у дітей старшого дошкільного віку. В учасників психокорекційної групи значно знизився рівень тривожності.Вони стали більш активними, в них покращився настрій. Діти почали більш вільно висловлюватися, демонструвати свої емоції та взаємодіяти між собою. Знизився також загальний рівень напруги в групі. Достовірність отриманих результатів підтверджена за допомогою $\mathrm{t}$ - критерія Стьюдента $(\mathrm{t}=5,1 ; \mathrm{p} \leq 0,01)$, що говорить про позитивну динаміку використання даного засобу при вирішенні проблеми тривожності дітей.

Висновки і перспективи подальших розвідок. У результаті проведення дослідження було виявлено, що застосування пісочної терапії в психокорекційній роботі з тривожними дітьми старшого дошкільного віку дає позитивні наслідки. Результати дослідження показали, що у більшості дітей експериментальної групи виявлені якісні позитивні зрушення щодо прояву тривожності та рівня самооцінки. У третини учасників корекційної групи тривожність знизилася до середнього рівня. Після проведення дослідження можна констатувати, що недостатня увага 3 боку батьків та проблеми в дитячо-батьківських взаєминах призводять до формування тривожного самовідчуття у дітей старшого дошкільного віку. Варто зазначити, що корекція даних станів необхідна для становлення гармонії у розвитку особистості дитини. Техніки пісочної терапії $\epsilon$ ефективними для використання під час психокорекційної практики з старшими дошкільниками. Під час гри дитина опрацьовує обставини, що пошкоджують психіку, на символічному рівні та ліквідує негативний емоційний досвід під час творчого самовираження.

У перспективі подальших досліджень ми планує розробити психологічний тренінг для батьків та дітей старшого дошкільного віку, щоб позбутися основних причин виникання явища тривожності.

\section{СПИСОК ПОСИЛАНЬ}

Буянов, М. І. (1990). Тайны детской психотерапии. Москва: Прометей.

Габуреева, Г. Ш. (2000). Основные аспекты проблемы тревожности в психологии. Тонус, 5, 32-39.

Гарбузов, В. И. (2001). Неврозы и психотерапия. Санкт-Петербург: Сотис.

Емельянов, Ю. Н. (1997). _Социально-психологическое проектирование в педагогике. Москва.

Захаров, А. И. (2000). Дневные и ночные страхи у детей. Санкт-Петербург.

Изард, К. Э. (2008). Страх и виды тревожности. Тревога и тревожность (с. 109-123). СанктПетербург.

Исурина, Г. Л. (1982). Динамика системы отношений больных неврозами в процессе групповой психотерапии. Исследования механизмов и эффективности психотерапии при нервно-психических заболеваниях (с. 57-63). Ленинград. 
Козлюк, О. А. (2010). Роль сім’ї у вихованні гуманістичної спрямованості спілкування дітей старшого дошкільного віку. Збірник наукових праць Бердянського державного педагогічного університету. Педагогічні науки, 3, 87-91.

Колосова, С. Л. (2004). Детская агрессия. Санкт-Петербург.

Кононко, О. Л. (2004). Соціально-емоиійний розвиток особистості (в дошкільному дитинстві). Київ.

Петровский, А. В., \& Ярошевский, А. В. (Ред.). (1985). Краткий психологический словарь. Москва: Политиздат.

Немов, Р. С. (2001). Психология (Т. 3). Москва: ВЛАДОС.

Омельченко, Я. М., \& Кісарчук, 3. (2011). Психологічна допомога дітям з тривожними станами (2-ге вид.). Київ: Шкільний світ.

Прихожан, А. М. (2000). Тревожность детей и подростков: психологическая природа и возрастная динамика. Москва: МПСИ; Воронеж: Изд-во НПО “Модек”.

Петровский, А. В. (1999). Возрастная и педагогическая психология. Москва.

Петровская, Л. А. (1986). Компетентность в общении. Москва: МГУ.

Райгороский, Д. Я. (2000). Практическая психодиагностика. Самара: Бахрах.

Салливан, Г. С. (1999). Интерперсональная теория в психиатрии. Москва: КСП; СанктПетербург: Ювента.

Спилбергер, Ч. Д. (2008). Концептуальные и методологические проблемы исследования тревоги. Тревога и тревожность (с. 85-99). Санкт-Петербург.

Уотс, А. У. (1997). Психотерапия. Восток и Запад. Львов: Инициатива.

Хорни, К. (2002). Тревожность. Тревога и тревожность, (с. 166-181). Санкт-Петербург.

\section{REFERENCES}

Buyanov, M. I. (1990). Secrets of Child Psychotherapy. Moskva: Prometheus.

Gabureeva, G. Sh. (2000). The main aspects of the problem of anxiety in psychology. Tonus, 5, 3239.

Garbuzov, V. I. (2001). Neuroses and psychotherapy. Sankt-Peterburh: Sotis.

Emelyanov, Yu. N. (1997). Socio-psychological design in pedagogy. Moskva.

Zakharov, A. I. (2000). Day and night fears in children. Sankt-Peterburh.

Izard, K. E. (2008). Fear and types of anxiety. Anxiety and anxiety (pp. 109-123). Sankt-Peterburh.

Isurina, G. L. (1982). Dynamics of the system of relations of patients with neuroses in the process of group psychotherapy. Research on the mechanisms and effectiveness of psychotherapy in neuropsychiatric diseases (pp. 57-63). Leningrad.

Kozlyuk, O. A. (2010). The role of family in the humanistic directing of children of senior preschool education. Collection of Science Practices of the Berdyansk State Pedagogical University. Pedagogical, 3, 87-91.

Kolosova, S. L. (2004). Children's aggression. Sankt-Peterburh.

Kononko, O.L. (2004). Social and emotional development of specialness (in preschool children). Kyiv.

Petrovsky, A. V., \& Yaroshevsky, M. G. (Red.). (1985). Brief psychological dictionary. Moskva: Politizdat.

Nemov, R. S. (2001). Psychology (T.3). Moskva: VLADOS.

Omelchenko, Ya. M., \& Kisarchuk, Z. (2011). Psychological help for children with anxious camps (2-he vyd.). Kyyiv: Shkil'nyy Svit.

Parishioners, A. M. (2000). Anxiety in children and adolescents: psychological nature and age dynamics. Moskva: MPSI; Voronezh: Publishing house of NPO Modek.

Petrovsky, A. V. (1999). Developmental and educational psychology. Moskva.

Petrovskaya, L. A. (1986). Competence in communication. Moskva: Moscow State University.

Raigorodsky, D. Ya. (2000). Practical psychodiagnostics. Samara: "Bakhrakh". 
Sullivan, G. S. (1999). Interpersonal theory in psychiatry. Moskva: KSP; Sankt-Peterburh: Juventa.

Spielberger, Ch. D. (2008). Conceptual and methodological problems of the study of anxiety. Anxiety and anxiety: a reader (pp. 85-99). Sankt-Peterburh.

Watts, A. U. (1997). Psychotherapy. East and West. L'vov: Initsiativa.

Horney, K. (2002). Anxiety. Anxiety and anxiety (pp. 166-181). Sankt-Peterburh.

\title{
SAND THERAPY AS A MEANS OF REDUCING ANXIETY IN CHILDREN OF SENIOR PRESCHOOL AGE
}

\author{
Inna Kariaka \\ Candidate of Psychological Sciences, Associate Professor, \\ Associate Professor of Pedagogy and Psychology of Vocational Education \\ National Aviation University \\ https://orcid.org/0000-0002-9570-7660 \\ Julia Khoroshchak \\ applicant for higher education in specialty 053 «Psychology» \\ educational and professional program «Practical Psychology» \\ National Aviation University
}

DOI https://doi.org/10.35619/praprv.v1i16.220

\begin{abstract}
The article reveals the essence of the concept of «anxiety,» as well as analyzes the main factors of this phenomenon, the peculiarities of its course, describe the most common methods of psychological protection of children: aggressive behaviour and fantasizing. The differences in anxious behavior of girls and boys of senior preschool age are highlighted and the consequences of fixing this feature are highlighted. The problem of anxiety correction in a preschool age is actualized because in this period there is a risk of consolidating it as a personality trait.

The article also describes an experimental study aimed at correcting the anxious behavior of older preschool children by sand therapy. Certain data of the research sample are given, the methodical tools on which it was performed are considered, the quantitative and qualitative analysis of the received data is given, and results of the research are described - a comparison of results before conducting psychocorrection and after.

According to the analysis of the results of the study, it is stated that there are quantitative changes in the results before and after correction, which proves the effectiveness of the use of sand therapy techniques when working with this age group. It turns out that the level of self-esteem, the peculiarities of the child-parent relationship and the psychological climate of the family are the main factors in the formation of anxious behavior of older preschool children.
\end{abstract}

Keywords: sand therapy, anxiety, preschool age. 